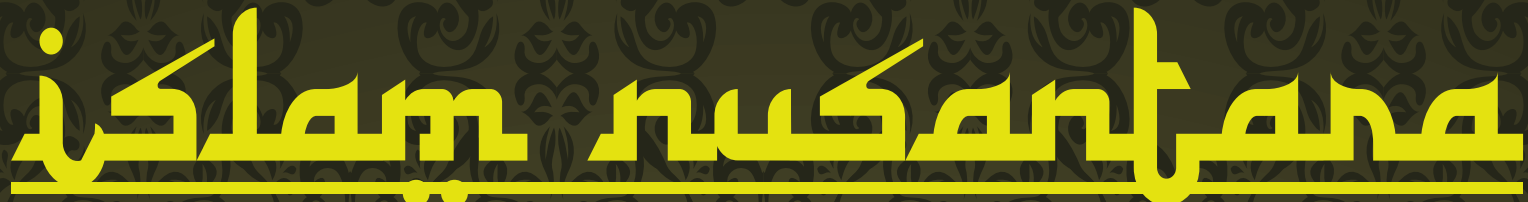

Journal for the Study of Istamic History and Callune

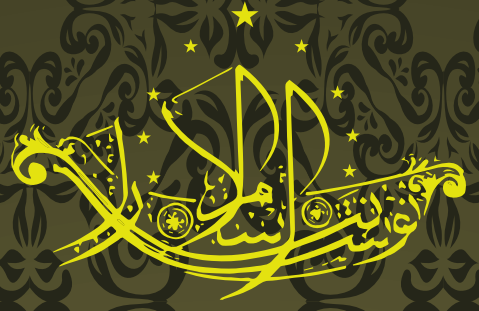

Exploring the Reality and Aspirations of Muslims

The divisions of the Umat in Indonesia

Hisanori Kato

Defending Islam Nusantara at the Frontline

Experiment to shape moderatism among Non-structural

Nahdliyyin Community

Hamdani

Bahasa dan Kekuasaan dalam Historiografi Islam Marshall G.S. Hodgson

Greg soetomo

Keberagamansemu dan Dilema Minoritas

dir Kota Banda Aceh

Teuku Kemal Fasya

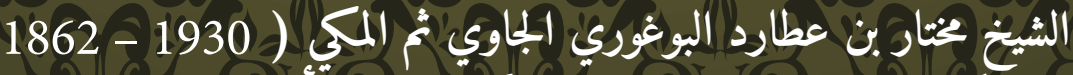

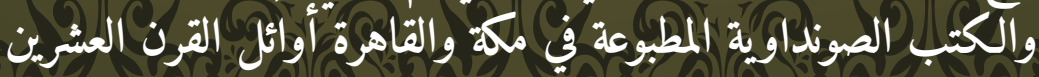

$$
\begin{aligned}
& \text { Ginanjar Sya'ban }
\end{aligned}
$$

\section{Book Review}

Jawa, Islam dan Nusantara:

Memposisikan Agama dalam Keragaman Budaya Riwanto Tirto Sudarmo 


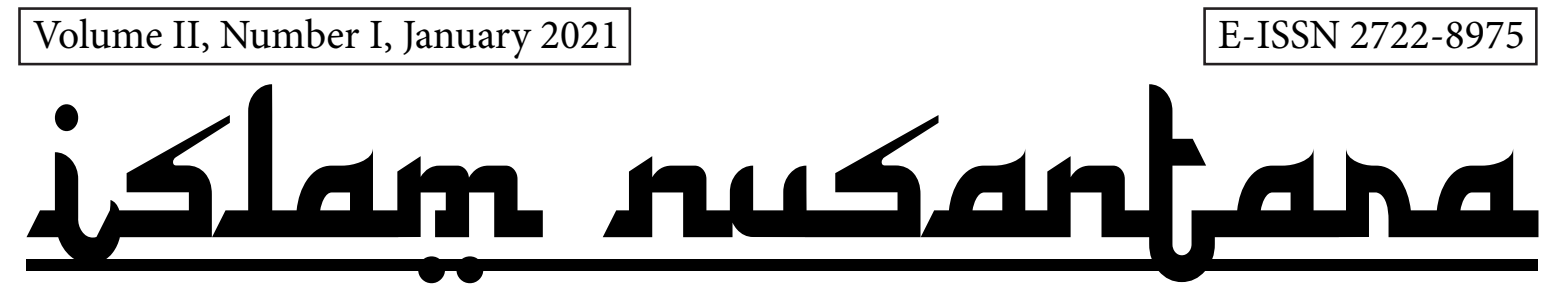

Journal for the Study of 7slamic History and Culture

Exploring the Reality and Aspirations of Muslims

The divisions of the Umat in Indonesia

Hisanori Kato

Defending Islam Nusantara at the Frontline

Experiment to shape moderatism among Non-structural

Nahdliyyin Community

Hamdani

Bahasa dan Kekuasaan dalam Historiografi Islam

Marshall G.S. Hodgson

Greg Soetomo

Keberagaman Semu dan Dilema Minoritas

di Kota Banda Aceh

Teuku Kemal Fasya

$$
\begin{aligned}
& \text { الشيخ مختار بن عطارد البوغوري الجاوي ثُ المكي ( } 1930 \text { - } 1862
\end{aligned}
$$

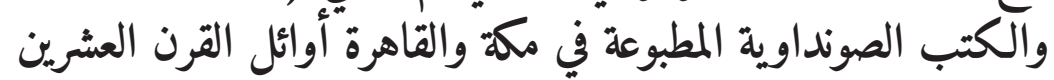

$$
\begin{aligned}
& \text { Ginanjar Sya'ban }
\end{aligned}
$$

Book Review

Jawa, Islam dan Nusantara:

Memposisikan Agama dalam Keragaman Budaya

Riwanto Tirto Sudarmo 


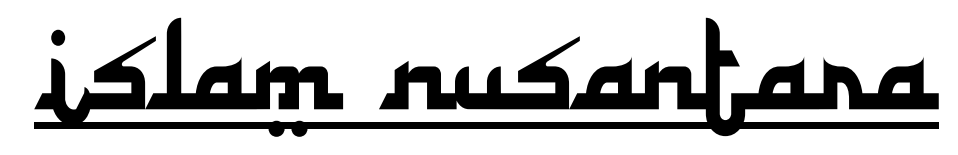

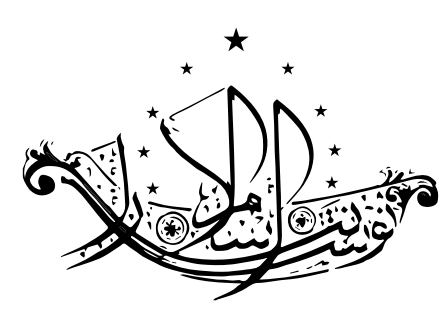




\section{Author Guideline}

I

slam Nusantara Journal for the Study of Islamic History and Culture facilitates publication of article and book review on study of Islam, Muslim culture, social and politics in Southeast Asia (Nusantara) and beyond. It is published twice a year and written in Indonesia, English and Arabic. It aims to present academic insight of social and cultural complexity of Muslim world in Southeast Asia under the frame of dialectic between Islam and local culture or cultural realities.

The journal invites scholars and experts working in various disciplines in the Islamic studies, humanities and social sciences. Articles should be original, research-based, unpublished and not under review for possible publication in other journals. All submitted papers are subject to review of the editors, editorial board, and blind reviewers.

Papers submitted for publication must conform to the following guidelines:

1. Papers must be typed in one-half spaced on A4-paper size;

2. Papers' length is about $8,000-10,000$ words;

3. All submission must include a 200-300 word abstract;

4. Full name(s) of the author(s) must be stated, along with his/her/their institution and complete e-mail address;

5. All submission should be in Microsoft Word, RTF, or WordPerfect document file format;

6. Arabic words should be transliterated according to the style of 'Islam Nusantara Studies';

7. Bibliographical reference must be noted in footnote and bibliography according to 'Islam Nusantara Studies' style.ain. 


\section{Examples of footnote style:}

${ }^{1}$ Ryan Sugiarto, Psikologi Raos: Saintifikasi Kawruh Jiwa Ki Ageng Suryomentaram, (Yogyakarta: Pustaka Ifada, 2015), p. 139.

${ }^{2}$ Nur Syam, Tarekat Petani: Fenomena Tarekat Syattariyah Lokal, (Yogyakarta: LkiS, 2013), p. 164.

${ }^{3}$ Syam, Tarekat Petani, p. 173.

${ }^{4}$ Ubaidillah Achmad dan Yuliyatun Tajuddin, Suluk Kiai Cebolek Dalam Konflik Keberagamaan dan Kearifan Lokal, (Jakarta: Prenada, 2014), p. 140.

${ }^{5}$ Nur Syam, Tarekat Petani, p. 99.

${ }^{6}$ M. Quraish Shihab, Tafsir Al-Misbah, vol. 14 (Bandung: Lentera Hati, 2013), p. 167.

${ }^{7}$ Deny Hamdani, "Cultural System of Cirebonese People: Tradition of Maulidan in the Kanoman Kraton," Indonesian Journal of Social Sciences 4, no. 1 (January-June 2012): p.12.

${ }^{8}$ Hamdani, "Cultural System of Cirebonese People," p. 14.

${ }^{9}$ Deny Hamdani, “Raison de’etre of Islam Nusantara," The Jakarta Post, 06 Agustus 2015, p. 5.

${ }^{10}$ Azyumardi Azra, "Islam di "Negeri Bawah Angin" dalam Masa Perdagangan," Studia Islamika 3, no. 2 (1996): h. 191-221, review buku Anthony Reid, Southeast Asia in the Age of Commerce (New Haven: Yale University Press, 1988).

\section{Example of Bibliography}

Suaedy, Ahmad. Gus Dur, Islam Nusantara dan Kewarganegaraan Bineka: Penyelesaian Konflik Aceh dan Papua 1999-2001. Jakarta: Gramedia, 2018.

Madjid, M. Dien dan Wahyudi, Johan. Ilmu Sejarah: Sebuah Pengantar. Jakarta: Prenada Media Group, 2014.

Banawiratma, JB. dkk., Dialog Antarumat Beragama: Gagasan dan Praktik di Indonesia. Bandung: Mizan Media Utama, 2010.

Sejarah Melayu/Malay Annals. Kuala Lumpur, Oxford University Press, 1970.

Tim Forza Pesantren. Ijtihad Politik Islam Nusantara:Membumikan Fiqih Siyasah Melalui Pendekatan Maqasid asy-Syariah. Kediri, Lirboyo Press, 2015.

Mastuki dan El-Saha, M. Ishom, ed. Intelektualisme Pesantren: Potret Tokoh dan Cakrawala Pemikiran di Era Pertumbuhan Pesantren. Jakarta: Diva Pustaka, 2003.

Suriasumantri, Jujun S. Ilmu Dalam Perspektif: Sebuah Kumpulan Karangan Tentang Hakekat Ilmu, Cet. XII. Jakarta: Yayasan Pustaka Obor Indonesia, 2012. 
Simuh. Sufisme Jawa: transformasi tasawuf Islam ke mistik Jawa. Yogyakarta: Yayasan Bentang Budaya, 1995. Reprint, Yogyakarta: Narasi, 2016.

Muhajir, Afifuddin, "Islam Nusantara untuk Peradaban Indonesia dan Dunia." Dalam Akhmad Sahal dan Munawir Aziz, ed. Islam Nusantara: Dari Ushul Fiqh Hingga Konsep Historis. Bandung: Mizan Pustaka, 2015.

Islam, Adib Misbahul. "Nazam Tarekat: Perlawanan Kiai Ahmad ar-Rifa’i terhadap Birokrasi." Dalam Islam Nusantara Past and Present:Proceeding of International Conference on Islam Nusantara (ICON) 2014. Jakarta: Pusmabit, 2014: h. 55-73.

Affan, Heyder. "Polemik di balik istilah 'Islam Nusantara." Artikel diakses pada 22 Juni 2015 dari http://www.bbc.com/indonesia/berita_indonesia/2015/06/150614_indonesia_ islam_nusantara

Malikov, Azim. "Islam: Saints and Sacred Geographies." Dalam Suad Joseph, ed. Encyclopedia of Women and Islamic Cultures, vol. V. Leiden: Brill, 2007: h. 223-225.

Hamdani, Deny. "Raison deetre of Islam Nusantara." The Jakarta Post, 06 Agustus 2015.

“Batunaga, Bagian dari situs lebih luas," Pikiran Rakyat, 16 Mei 2014.

Hamdani, Deny. "Cultural System of Cirebonese People: Tradition of Maulidan in the Kanoman Kraton." Indonesian Journal of Social Sciences 4, no. 1 (January-June 2012): h.12.

Hosen, Nadirsyah. "Islam Nusantara: Islam Lokal yang Menuju Islam Global?" Gatra, 2 Maret 2016, h. 60.

El-Mawa, Mahrus. "Syattariyah wa Muhammadiyah: Suntingan Teks, Terjemahan dan Analisis Karakteristik Syatariyah di Keraton Kaprabonan Cirebon Pada Akhir Abad ke-19.” Disertasi S3 Fakultas Ilmu Pengetahuan Budaya, Universitas Indonesia, 2015.

Azra, Azyumardi. "Islam di "Negeri Bawah Angin" dalam Masa Perdagangan." Studia Islamika 3, no. 2 (1996): h. 191-221. Review buku Anthony Reid, Southeast Asia in the Age of Commerce. New Haven: Yale University Press, 1988.

Taimiyya, Ibnu. Minhaj as-Sunnah an-Nabawiy. T.tp.: Darul Urubiyya, 1962.

Dawud, Abu. Sunan. Kairo: T.pn., 1951.

Bajuri, Ibrahim. Hasyiah al-Bajuri 'ala Matn al-Burdah. Bandung: Darul Ma’arif, t.t. 


\section{Guidelines for Book Reviews}

1. Please include, at the beginning of the review:

Author, Title, Place, Publisher, Date, number of pages, ISBN E.g., Turabian, Kate L. A Manual for Writers of Term Papers, Theses, and Dissertations. Sixth edition. Chicago and London: University of Chicago Press, 1996. $308+$ ix pp. ISBN: 0-226-81627-3.

2. The review should begin with a brief overall description of the book.

3. Matters that may be considered in the body of the review include:

The strengths and weaknesses of the book.

Comments on the author's style and presentation.

Whether or not the author's aims have been met.

Errors (typographical or other) and usefulness of indices.

Who would the book be useful to?

Would you recommend it for purchase?

4. The average review should be about 3000 words long. The name, affiliation and email address of the reviewer should appear at the end of the review.

5. The preferred format for submissions is MS-Word. 


\section{islam nusantane \\ Journal for the Study of Islamic History and Culture}

Volume II, Number I, January 2021

\section{EDITOR-IN-CHIEF}

Ahmad Suaedy, (Scopus ID: 56419869500) Faculty of Islam Nusantara UNUSIA, Jakarta

\section{MANAGING EDITOR}

Ngatawi El-Zastrow, Faculty of Islam Nusantara UNUSIA, Jakarta

\section{INTERNATIONAL EDITORIAL BOARD}

Said Aqil Siradj, Faculty of Islam Nusantara UNUSIA, Jakarta

Robert W. Hefner, (Scopus ID: 36856758800) Boston University, Boston USA

Okamoto Masaaki, (Scopus ID: 57191206120), Kyoto University, Kyoto Japan

Dien Madjid, State Islamic University Syarif Hidayatullah Jakarta, Jakarta

Endang Turmudzi, Indonesian Institute of Sciences (LIPI)

Alwi A. Shihab, Indonesian Muslim Intellectual and expert on Middle East Studies and Muslim Civilization James Bourk Hoesterey, Emory University, Atlanta GA, USA

Hisanori Kato, (Scopus ID: 55996362300), Chuo University, Tokyo Japan

Abdul Moqsith, State Islamic University Syarif Hidayatullah Jakarta, Jakarta

Sahiron Syamsuddin, (Scopus ID: 55996362300) State Islamic University Sunan Kalijaga, Yogyakarta

Muhammad Ishom, State Islamic University Sultan Maulana Hasanuddin, Banten

Azhar Ibrahim, (Scopus ID: 7202979037) National University of Singapore, Singapore

ADVISORY EDITORS:

Hamdani, (Scopus ID: 57200648495) Faculty of Islam Nusantara UNUSIA, Jakarta

\section{EDITORIAL BOARD:}

Maria Ulfah, Faculty of Islam Nusantara UNUSIA, Jakarta

Ulil Abshar Abdalla, Faculty of Islam Nusantara UNUSIA, Jakarta

Syamsul Hadi, Faculty of Islam Nusantara UNUSIA, Jakarta

Ali Abdillah, Faculty of Islam Nusantara UNUSIA, Jakarta

Ayatullah, Faculty of Islam Nusantara UNUSIA, Jakarta

Ulil Abshar, State Islamic University Syarif Hidayatullah, Jakarta

Ahmad Ginandjar Sya'ban, Faculty of Islam Nusantara UNUSIA, Jakarta

Idris Masudi, Faculty of Islam Nusantara UNUSIA, Jakarta 


\section{PEER REVIEWERS}

James Bourk Hoesterey, Emory University, Atlanta GA, USA

Hisanori Kato, (Scopus ID: 55996362300), Chuo University, Tokyo Japan

A Gaffar karim, Gadjah Mada University, Yogyakarta

Tri Chandra Arifianto, University of Jember, Jember

Jajang Jahroni, State Islamic University Syarif Hidayatullah, Jakarta

Yunus Masrukhin, State Islamic University Sunan Kalijaga, Yogyakarta

Faried F. Saenong, Victoria University of Wellington, Wellington, New Zealand

Merry Kolimon, Artha Wacana Christian University, Kupang

Falikul Isbah, Gadjah Mada University, Yogyakarta

Zacky K. Umam, Abdurrahman Wahid Centre, University of Indonesia, Depok

Arif Zamhari, State Islamic University Syarif Hidayatullah, Jakarta

Amri Marzali, University of Indonesia, Depok

ISLAM NUSANTARA: Journal for the Study of Islamic History and Culture facilitates the publication of article and book review on study of Islam, Muslim culture, social, politics and history in Southeast Asia (Nusantara) and beyond. It is published twice a year and written in Indonesia, English and Arabic. It aims to present academic insight of social and cultural complexity of Muslim world in Southeast Asia under the frame of dialectic between Islam and local culture or cultural realities.

The journal invites scholars and experts working in various disciplines in Islamic studies, humanities, and social sciences. Articles should be original, researchbased, unpublished and not under review for possible publication in other journals. All submitted papers are subject to a review of the editors, editorial board, and blind reviewers.

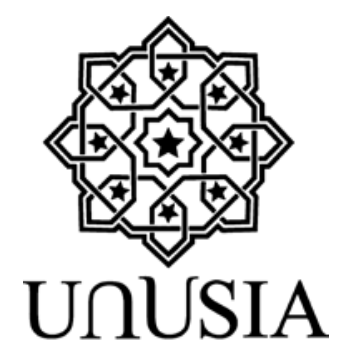

EDITORIAL JOURNAL

Gedung Kampus UNUSIA Lantai 2

Jl. Taman Amir Hamzah No. 5 Jakarta Pusat 10430

E-mail: Islamnusantarajournal@unusia.ac.id or Journalofislamnusantara@gmail.com

Website : http://journal.unusia.ac.id/index.php/

ISLAMNUSANTARA/about 


\section{Table of Contents}

Articles

1

Exploring the Reality and Aspirations of Muslims

The divisions of the Umat in Indonesia

21 Hamdani

Defending Islam Nusantara at the Frontline

Experiment to shape moderatism among Non-structural

Nahdliyyin Community

41 Greg Soetomo

Bahasa dan Kekuasaan dalam Historiografi Islam

Marshall G.S. Hodgson

71 Teuku Kemal Fasya

Keberagaman Semu dan Dilema Minoritas di

Kota Banda Aceh

93 Ginanjar Sya'ban

$$
\begin{aligned}
& \text { الشيخ مختار بن عطارد البوغوري الجاوي ثم المأكي ( } 1930 \text { - } 1862
\end{aligned}
$$

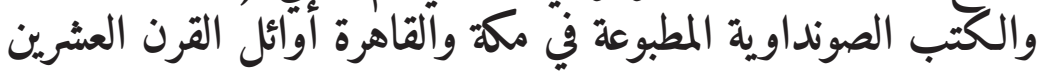

Book Review

113 Riwanto Tirto Sudarmo

Jawa, Islam dan Nusantara:

Memposisikan Agama dalam Keragaman Budaya 
Hisanori Kato

\title{
Exploring the Reality and Aspirations of Muslims ${ }^{1}$
}

\section{The divisions of the Umat in Indonesia}

Chuo University, Tokyo

kato.15x@g.chuo-u.ac.jp

\begin{abstract}
$\mathrm{I}$

slam in Indonesia has played an important role in socio-political development in its recorded history. However, it is also true that there have been various theological and political debates and disagreements in the umat. The implementation of syariat Islam is one of the major subjects of such discussions. The emergence of liberal movement in the post-Suharto era also brought about the difference of opinion among Muslims. In other words, the umat has never been united as a single entity in Indonesia. This "divided" umat faces several challenges in the present day in Indonesia. That includes terrorism committed by militant Muslims. In addition to the effort to prevent terrorism, it is equally important to de-radicalise perpetrators of such violent and barbaric acts. Despite some discrepancy in the umat, we see several attempts and cooperation of Muslims to make former terrorists reintegrated in the society. This paper shows how the re-radicalisation programme for former terrorist executed. The author also intends to examine the sociopolitical development of the umat in modern Indonesia with regard to subjects of syariat Islam and liberal movement. Based on these examinations, sociological analysis on religion is also presented in the paper.
\end{abstract}

Keywords: syariat, religious organism, terrorism, de-radicalisation, JIL

1 Supported by Kaken No.20K12375. 


\section{Abstrak}

Islam di Indonesia telah memainkan peran penting dalam sejarah pembangunan sosial dan politik. Namun, menjadi kenyataan pula bahwa telah terjadi berbagai perdebatan teologis dan politik serta ketidaksepakatan yang berlangsung dalam tubuh umat. Implementasi syariah adalah salah satu subjek utama dalam pembahasannya. Kemunculan gerakan liberal pasca 'Era Suharto' juga telah menyebabkan perbedaan pendapat di kalangan umat Islam. Dengan kata lain, umat tidak pernah bersatu sebagai sebuah entitas tunggal di Indonesia. Ini juga termasuk berbagai aksi terorisme yang dilakukan oleh kaum Muslim militan. Selain upaya untuk mencegah terorisme, hal yang sama pentingnya adalah upaya deradikalisasi pelaku teror atas kekerasan dan tindakan barbar yang telah dilakukan. Meskipun terjadi ketidakcocokan di kalangan internal umat Islam, kita melihat beberapa usaha dan kerjasama antar Muslim berlangsung dalam rangka membuat mantan teroris kembali ke masyarakat. Paper ini menunjukkan bagaimana program deradikalisasi bagi mantan teroris dilaksanakan. Penulis juga bermaksud menginvestigasi perkembangan sosial-politik umat di masa Indonesia modern dengan melihat syariat Islam dan gerakan liberal. Berdasarkan investigasi ini, analisis sosiologis tentang agama juga dihadirkan dalam paper ini.

Kata kunci: syariat, organisme agama, terorisme, de-radikalisasi, JIL

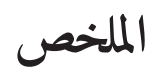

إن الإسلام في إندونيسيا قدٍ لعب دورًا مهمًا في التنمية الاجتماعية والسياسية عبر تاريخه المسجل.

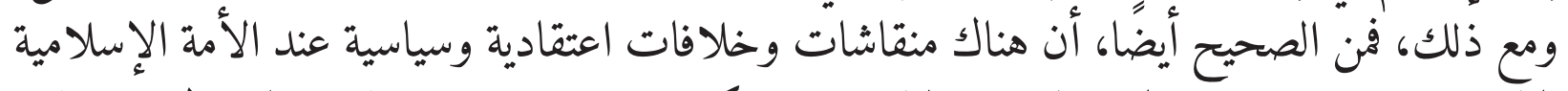

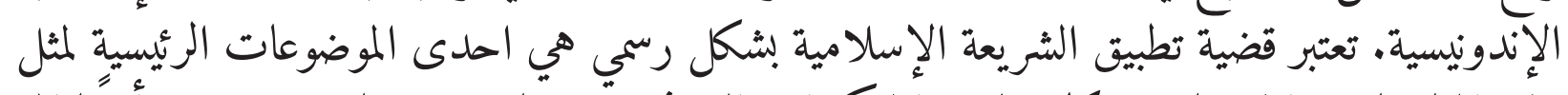

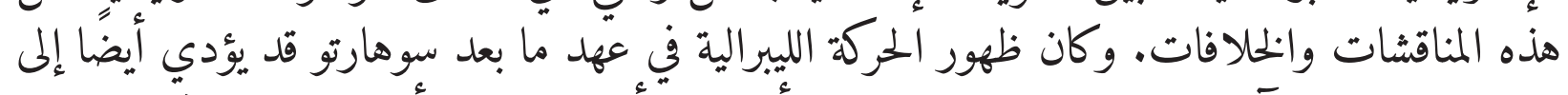

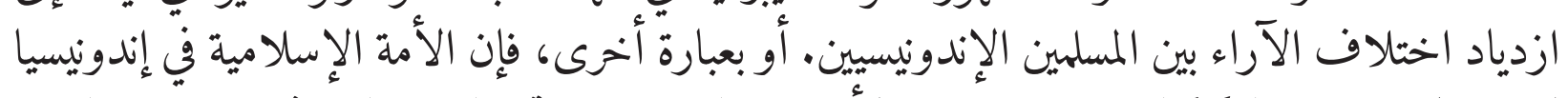

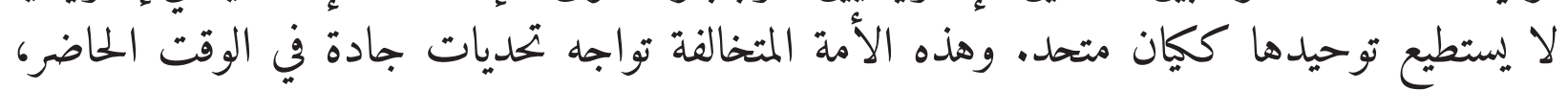

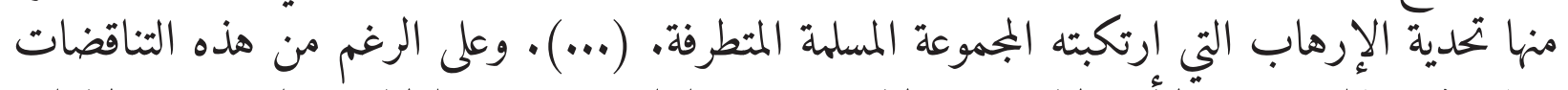

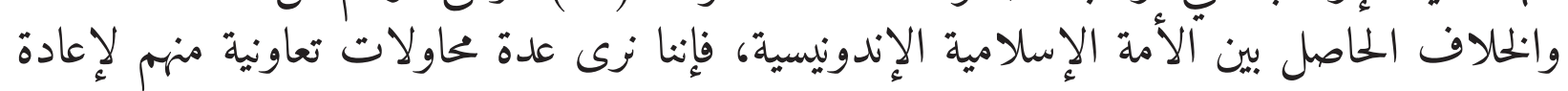

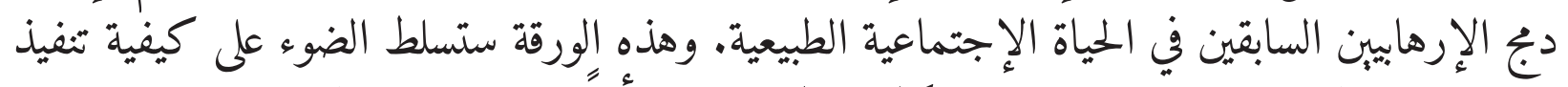

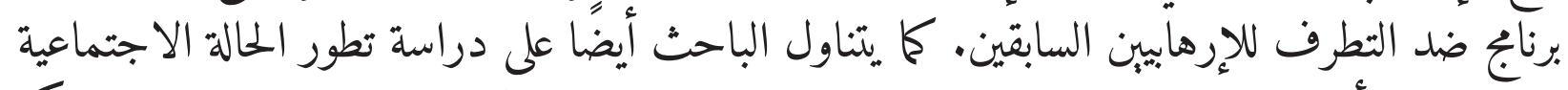

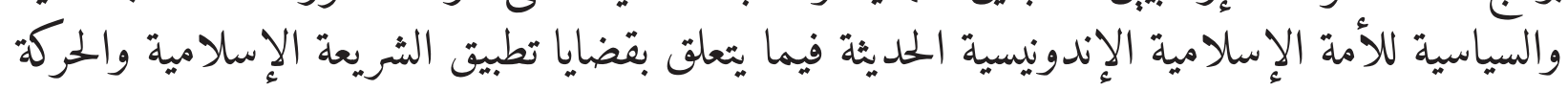

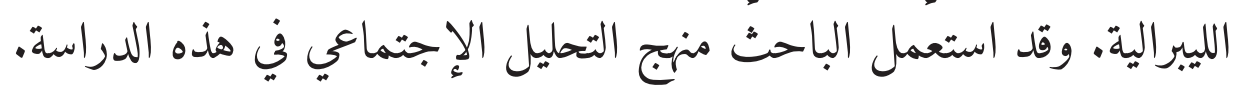
الكلمة الاساسية : الشريعة ، الكائنات الدينية ، الارهابي، نزع التطرف، الحركة الليبرالية

Our people possessed a quality which lived deeply rooted in their very bones, to wit: the quality to which we often refer as gotong-royong [mutual aid]. ..... In brief, it can be said we 
have a homeland still clear of the seeds of that which is capable of causing upset. ${ }^{2}$

\section{Introduction}

Indonesia has been on the radar of the international community due to its rapid economic growth since the end of 1990s. ${ }^{3}$ Before 2000, people used to visit public phone houses called wartel to communicate with their families and friends; they now possess their own portable devices, such as smart phones. In addition, the long-awaited intercity railway system in Jakarta, Mass Rapid Transit, began operations in March 2019. These remarkable social changes exemplify the characteristics of contemporary Indonesia, yet we also find a distinctive traditional quality in this largest of nations in Southeast Asia: a long-standing history of socio-cultural diversity and the dominance of Islam.

Before the advent of Islam, both Buddhism and Hinduism widely prevailed over the archipelago. Srivijaya, which thrived between the $7^{\text {th }}$ and the $14^{\text {th }}$ centuries in southern Sumatra, was a powerful Buddhist empire, exercising its influence over the region. Another Buddhist kingdom called Shailendra in Central Java built the Borobudur Temple in the $8^{\text {th }}$ century. Hinduism, on the other hand, is still deeply rooted in the soil of Bali, existing alongside the influence of an exquisite native Indonesian culture. Hindu Prambanan temples in Central Java, which were erected in the era of Old Mataram, are another conspicuous legacy of pre-Islamic civilisation in Indonesia. In addition to these established religions, indigenous animistic beliefs also continue to be held in the present. ${ }^{4}$

Diversity in Indonesia applies not only to religions but also to the multitudinous ethnic groups. It is said that there are about three hundred tribes and between two hundred and four hundred local languages spoken in Indonesia. ${ }^{5}$ Bountiful different traditional dances and dresses which still exist in the present are vivid examples of Indonesia's multicultural conventions. However, even with these diverse socio-cultural traditions intact, Islam has become the dominant religion in the region with almost 205 million worshippers, making Indonesia the most populous Muslim nation in the world. ${ }^{6}$ Concurrently, despite the great presence of Islam, Indonesia has maintained a republicanism since its independence and has not implemented Islamic law (syariat) as the legal foundation of the country. It is understandable, then, that Indonesia puts forth the notion of Bhinneka Tunggal Ika, or Unity in Diversity, as a national motto.

Throughout its modern history, Islam has been a salient element for both the actualisation of stability and, conversely, the creation of disturbance in Indonesian society. In trying to come to terms with Bhinneka Tunggal Ika, Islam, as a majority religion, has always been tested in its tolerance and stance on non-Muslims and on topics related to Islamic and non-Islamic discourse. It is important to remember that the Islamic community (the

2 Muhammad Natsir, “The Indonesian Revolution,” in C. Kurzman(ed.). Liberal Islam, (New York: Oxford University Press, 1998), p.62. Natsir served as Prime Minister of the Republic from 1950 to 1951 . In the early 1950s, he supported the idea of a secular state. However, he changed his view and was involved in the Islamic Revolutionary Movement in Sumatra in 1958 and was imprisoned. The above statement was written in 1955.

3 Indonesia as a member of the G20 has the tenth largest purchasing power parity in the world. https://www. worldbank.org/en/country/indonesia/overview

4 John David Legge Indonesia, (Englewood Cliffs: Prentice-Hall, 1964) p.2.

5 Mizumoto, T. Indonesia. (Tokyo: Chuokoron-Shinsha, 2006), p.vi.

6 Pew Research Centre, Religion and Public Life: https://www.pewforum.org/2010/11/04/muslimpopulation-of-indonesia/ 
umat) in Indonesia was heterogeneous in bygone days. Such dissimilarity in the umat can be attributed to divergent theological interpretations and to the differing socio-cultural backgrounds of each individual or group represented by various Islamic organisations.

We find different aliran (currents) in the umat, and the most commonly framed categorisations are modernist and traditionalist Islam, represented by Muhammadiyah and Nahdlatul Ulama (NU), respectively. Needless to say, these two mass Islamic organisations still exhibit their differences at the present times; however, it is more common that they cooperate in the face of various social issues. Both of them have already embraced republicanism and seem determined to contribute to the creation of a peaceful and tolerant religious community in Indonesia. In that sense, Natsir might be right that Indonesia is a country of mutual-help and is free from conflicts. Nevertheless, there seem to be numerous predicaments that the umat must deal with. These include acts of terrorism, the stance of Islam towards other religions, and even sectarian discord among Muslims.

This paper is an attempt to clarify the crux of the socio-religious issues that the umat encounters in modern Indonesia. In other words, it will attempt to uncover the reality behind the largest umat in the world. The author believes that it is worth exploring how Islam in Indonesia interacts with different groups within and outside of Islam, which will reveal a unique model of how Islam carries on in the contemporary world.

\section{Syariat Islam and Modern Indonesia}

The end of the World War II simultaneously marked the end to the more than threecentury-long colonisation of Indonesia by the Dutch and the Japanese. Although at that time Japanese government occupied Indonesia(and other Asian nations) under the pretext that a Great Asia Co-Prosperity Sphere (Daitoa Kyoeiken) should be established, historical documents clearly reveal that the main purpose of Japan's invasion of Indonesia was to secure natural resources. ${ }^{7}$ This suggests that the interest of Japan was by no means to liberate the people living in the Indonesian archipelago from Dutch colonisation. Ricklefs believes that the defeat of Japan, in fact, had a positive impact on Indonesian independence. ${ }^{8}$

As the defeat of Japan in the war became more obvious, Badan Penyelidik Usaha Persiapan Kemerdekaan Indonesia (the Investing Committee for Preparatory Work for Indonesian Independence) was formed in March 1945. ${ }^{9}$ This group was supposed to determine the course of Indonesia's future. The members of this committee were from various religious communities, and a prominent nationalist leader, Sukarno, was also an important member. It was a crucial moment for the umat, as the role of Islam in a new nation was intensively discussed. There were some Muslim leaders who insisted that Islam play a broader overall roll in the society via the implementation of syariat. As of June 1945, the committee agreed that the president should be a Muslim and that syariat should be observed by the followers of Islam. ${ }^{10}$ This document, called "Jakarta Charter" or Piagam Jakarta, clearly stated that "for the followers of Islam, they have an obligation to follow syariat" and to believe in God

7 Goto, K. Tonanajia karmita Kindain Nippon (Modern Japan from Southeast Asian Prespectives). (Tokyo: Iwanamishoten, 2012). p. 44.

8 Merle C. Ricklefs. A History of Modern Indonesia Since c. 1300. (London: Macmillan, 1993), p,199.

9 Merle C. Ricklefs. A History of Modern Indonesia, p. 208, this committee was replaced by Panitia Persiapan Kemerdekaan Indonesia (Preparatory Committee for Indonesian Independence) known as PPKI on $7^{\text {th }}$ August, 1945.

10 Robert Cribb and Collin Brown. Modern Indonesia A History since 1945. (London: Longman, 1995), p.15. 
(dengan kewajiban menjalankan syariat Islam bagi pemeluk-pemeluknya). Nonetheless, when the new constitution for the Republic was promulgated, the Jakarta Charter was excluded and the criteria that the president be a Muslim was also dropped. ${ }^{11}$

Not surprisingly, the omission of the Jakarta Charter from the constitution was demanded by non-Muslim groups, such as Christians. ${ }^{12}$ Sukarno, the leader of the new country, understandably made the decision to prioritise an equilibrium among religious groups, as a potential threat for the Republic was disintegration based on religions and ethnic identities. Presumably, however, this political decision of Sukarno brought about a feeling of dissatisfaction and even a feeling of insult for those who had intended to implement syariat in the new nation. In fact, there were attempts by Islamic political parties to reinstate the Jakarta Charter in 1959 and 1968 but in vain. ${ }^{13}$ The majority of the umat seems to follow the course set by Republic of Indonesia regarding the status of syariat. ${ }^{14}$ However, some Muslims have disagreed with the policies and have decided to continue their struggle to realise their Islamic aspirations underground. Unfortunately, some of these Muslims have employed destructive means against the government.

\section{Suharto and the Umat}

Suharto, the successor of Sukarno, was in power for more than three decades between 1966 and 1998, and his regime was coined "the New Order government". Although Islam was one of the most influential social elements in the country during this time, the umat was heedful of Suharto's government, whose orientation was rather dictatorial. M. Natsir, whose statement was cited at the beginning of this paper, was charged because he stated the government treated Muslims as "cats with ringworm". ${ }^{15}$ While the majority of Muslims were accommodating, some took more confrontational stances towards the New Order government. Some Muslims, in fact, voiced their resentment against Suharto in the early phases of the government. For example, they expressed their disapproval when the government attempted to implement a marriage law in $1973 .{ }^{16}$ In addition, there was a clash between the supporters of the ruling Golkar and the Islamic party Partai Persatuan Pembangunan (PPP) during the election campaign of $1982 .{ }^{17}$

The underground activities of rather hard-line Muslims, who probably held a grudge due to the decision of the Republic to discard the Jakarta Charter, began to include physical resistance. Presumably, these rigid Muslims were discontent with Suharto's stance towards working with non-Muslim Chinese Indonesian conglomerates, insisting that they monopolised businesses and exploited native Muslim Indonesians (pribumi). One of the most serious challenges against Suharto's regime was the hijacking of an aeroplane of the

11 Merle C. Ricklefs, A History of Modern Indonesia, p. 213.

12 Merle C. Ricklefs, A History of Modern Indonesia, p. 213.

13 Merle C. Ricklefs, Islamisation and Its Opponents in Java c.1300 to the Present, (Honolulu, 2012), p.117.

14 Muslims who wished to implement syariat in Indonesian society gathered under the political party Masyumi, which was banned by Sukarno in 1960, as it was involved in an attempt to rebel against the central government.

15 Edward Aspinall, Opposing Suharto. (Stanford: Stanford University Press, 2005), p.39.

16 John Bresnan, Managing Indonesia. (New York: Columbia University Press, 1993), p.235. See also Hisanori Kato, "Religion and its Functions in Society: Islam and the Creation of a Democratic Civilised in Indonesia with Special Attention to Nahdlatul Ulama, Muhammadiyah and Ikatan Cendekiawan Muslim Indonesia, Ph. D thesis, The University of Sydney, 1999, p. 126.

17 Bresnan, Managing Indonesia, p.236; Hisanori Kato, Religion and its Functions, p. 127. 
national flag carrier Garuda Indonesia in 1981. The culprits of this crime expressed their motivation by saying that "they were "eager that the teachings of Islam should be fully put into practice". ${ }^{18}$

Some have pointed out that more-politically oriented Muslim groups were a threat to the New Order government in the 1970s and 1980s. ${ }^{19}$ Even though the portion of these Muslims that engaged in physical resistance against Suharto in the umat remained rather small, the New Order government introduced a new regulation forcing all social organisations, including Islamic ones, to embrace Pancasila as a first principle(asas tunggal) in $1985 .{ }^{20}$ Prior to the formal implementation of this policy, a large scale clash between government forces and Muslims groups took place in September 1984 in Tanjung Priok, an area in north Jakarta. ${ }^{21}$ In fact, during this period of the New Order, there were a series of violent incidents, such as the bombing of a Chinese Indonesian-owned Bank Central Asia building and the Borobudur Buddhist monument. Cribb and Brown discerned that "Islamic resentment" towards the secularisation of Muslim-dominated Indonesia influenced Muslim resistance. ${ }^{22}$ As Suharto kept a tight grip, cracking down on violent Muslim extremists, some Muslims chose to leave Indonesia, including the charismatic Muslim preacher Abu Bakar Baasyir.

While some hard-line Muslims expressed their "resentment" and were even involved in terrorist acts, the large portion of the umat represented by mass Islamic organisations still maintained an accommodative attitude towards the New Order regime, although this may have been a tactical decision. While NU, led by their new leader Abdurrahman Wahid (popularly known as Gus Dur), endorsed Pancasila in 1984, which was prior to its legal enforcement, Muhammadiyah, although more reluctantly than NU, also accepted Pancasila, as if, in the words of Chairperson H.A.R. Fachruddin, they wore a "safetyhelmet" while riding a motor cycle. ${ }^{23}$ Nonetheless, it is mistaken to believe that these mass Islamic organisations were subdued by Suharto completely. Aspinall points out that both NU and Muhammadiyah maintained their "semi-oppositional accommodation with the government". ${ }^{24}$ Furthermore, the outspoken Gus Dur never abandoned his critical attitude towards Suharto and often had conflicts with the supreme leader. Indeed, there was a time when Gus Dur referred to Suharto as "stupid" while being interviewed by a foreign scholar, which invited the indignation of Suharto.

The relationship between supreme leader Suharto and the umat started to change when a new state-sponsored Islamic organisation, Ikatan Cendekiawan Muslim Indonesia (Indonesian Association of Muslim Intellectuals or ICMI), was established in 1990. Some point out that the formation of ICMI was Suharto's attempt to create a support group at a time when he had less support from the military. ${ }^{25}$ With an emergence of this new

\footnotetext{
18 Cited by Hisanori Kato, Religion and its Functions, p. 127.

19 Aspinall, Opposing Suharto, p.39.

20 Aspinall, Opposing Suharto, p. 38.

21 Aspinall, Opposing Suharto, p. 38.

22 Cribb and Brown, Modern Indonesia, p.143.

23 Hisanori Kato, Religion and its Functions, p. 241, original statement was cited by M. Sirajuddin Syamsuddin. Religion and Politics in Islam: The Case of Muhammadiyah in Indonesia's New Order, Ph. D thesis. UCLA, 1991, p. 245. In relation to the acceptance of Pancasila, some Islamic groups such as Persatuan Pelajar Islam (Union of Muslim Students) refused to endorse it, and thus it was banned by the government.

24 Aspinall, Opposing Suharto, p. 39.

25 Aspinall, Opposing Suharto, p. 40.
} 
Islamic organisation, the division of the umat was widened. On the one hand, quite a few prominent Muslim leaders, scholars, and politicians who used to be "semi-oppositional" to the government joined the association. On the other, some Muslim leaders refused to be members of ICMI. Muhammadiyah's Amien Rais was a typical example of the former, and Gus Dur was a representation of the latter.

Gus Dur firmly believed that ICMI was sectarian and a potential threat to minority groups in the society. Conversely, some Muslim leaders thought that a genuine reformation reflecting Islamic aspirations was only possible when working within the system. From the beginning of the independence period to the early stage of the New Order government, the main concern of the umat was the issue of syariat (the Jakarta Charter) in Indonesia, which created rather rigid and uncompromising Muslim groups, some of which were involved in unlawful underground activities. From 1990 onwards, however, the umat was divided into pro-ICMI and anti-ICMI groups, i.e., the reformers within the government and the reformers outside the government.

\section{Post-New Order and the umat}

The end of the New Order in 1998 brought about an overall reformation (Reformasi ) of Indonesian society. The issue of human rights started to be paid more attention to, and the importance of freedom of expression acquired greater recognition after the authoritarian regime collapsed. This transformation also assured unrestricted activities for Muslims regardless of their religious standpoint. This resulted in the return of rigid hardliner Muslims who had fled Indonesia during the dictatorial rule of Suharto. As Reformasi progressed, the umat seemed to have entered a new phase in Indonesian history. While both NU and Muhammadiyah steadfastly represented the mainstream of the umat, there emerged two other opposing trends: an extremely rigid Salafist type group on one hand, and an extremely moderate group with a willingness to offer unconventional interpretations of Islamic teachings on the other. The rigid hardliner Muslims in exile during the time of the New Order belonged to the former group, and predominantly young Muslim intellectuals represented the latter.

In the post Reformasi period, Indonesia unfortunately witnessed some barbaric terrorist acts committed by splinter groups of rigid hardliner Muslims. These include the bombings in Bali in 2002 and 2005, the bombing of the Australian Embassy in 2004, and the bombings of the Marriot Hotel in Jakarta in 2003 and 2009. One might misconceive rigid Muslims eager to implement syariat and the perpetrators of these terrorist acts as being identical in their ideas and attitudes. Although they might share mutual aims, their methodology for realising their religious purposes differs fundamentally. Terrorists opt to take weapons and kill fellow humans indiscriminately for their political ends, while rigid hardliners reject any acts that contradict syariat, such as killing without a proper pretext. Rigid hardliners also choose to continue their proselytising activities through discussions and religious sermons.

Another conspicuous development in the umat in the 2000s was the active campaign of so-called "liberal Islam", known as Jaringan Islam Liberal (JIL) or the Liberal Islam 
Network. ${ }^{26}$ Ulil Abshar Abdalla, for one, vigorously promoted an open-minded attitude for Muslims with the unconditional acceptance of Republicanism. Abdalla invited controversy when he expressed his opinion on jilbab (a headscarf for Muslim women) in a newspaper article, saying that wearing jilbab was an Arabian tradition; thus, it was not compulsory for Muslim women in Indonesia. ${ }^{27}$ Young Muslim intellectuals from this liberal circle were greatly influenced by their predecessors, including Djohan Effendi, Dawam Raharjo, Nurcholish Madjid, Ahmad Wahib, and Gus Dur. ${ }^{28}$ In that sense, the emergence of such "liberal Muslims" in the umat was by no means instantaneous. However, what distinguishes them from the former generation was their complete acceptance of secularism, other faiths, and even their method to convey their ideas to the public. Luthfi Assyaukanie, a colleague of Abdalla, explained that liberal democracy should be the base of a society where religious freedom and pluralism are assured. ${ }^{29}$ Therefore, for them, secularism was highly valued for helping to realise an ideal state rather than an Islamic one based on syariat.

Assyaukanie also rejected an Islamic attitude that subordinates other faiths. ${ }^{30}$ Panikkar explains different attitudes regarding the relationship among religions, including, exclusivism, inclusivism, parallelism, pluralism. In his own words:

a. Exclusivism, A believing member of a religion in one way or another considers his own religion to be true. ...b. Inclusivism, ... The inclusivistic attitude will tend to reinterpret things in such a way as to make them not only palatable but also assimilable. ... This attitude has a certain quality of magnanimity and grandeur in it. You can follow your own path and do not need to condemn the other. c. Parallelism ... Religions would then be parallel paths and our most urgent duty would be not to interfere with others... d. Interpenetration ...the other is not so independent from us and is somehow touched by our own beliefs. e. Pluralism ... It is not to win over the other or to come to a total agreement or universal religion. ${ }^{31}$

Based on Panikkar's account, liberal Muslim intellectuals obviously adhere to the idea of pluralism, which embraces and acknowledges the values of all religions. The supremacy of Islam among other religions is one of the core teachings of Islam, as al-Quran confirms: "The only true faith in God's sight is Islam"...(al-Imran-19), and "He that chooses a religion other than Islam, it will not be accepted from him and in the world to come he will surely be among the losers"...(al-Imran-85). Nonetheless, a new generation of Muslim intellectuals showed little hesitance in expressing an interpretation that acknowledges the equality of all religions, exercising their ijtihad. JIL also protected the rights of the Ahmadiyah Muslim Community and promoted interreligious marriage and gender equality. ${ }^{32}$

26 See the development of JIL, Ahmad Bunyan Wahib. Liberal Islam in Indonesia. (Saarbrucken: Lambert Academic Publishing, 2012).

27 Ulil Abshar Abdalla "Menyegarkan Kembali Pemahaman Islam". Kompas 18 November 2018. Because of this article, he received a death threat, and more threats followed afterwards. On one occasion, an explosive package was sent to his office in Jakarta in 2011, but he was able to escape.

28 Carool Kersten, Islam in Indonesia The Contest for Society, Ideas and Values. (London: Hurst \& Company, 2005), p. 226-262.

29 Luthfi Assyaukanie, “Debates on Islam and Secularism in Indonesia." In Hisanori Kato, (ed.) The Clash of Ijtihad, Fundamentalist versus Liberal Muslims. (Delhi: ISPCK, 2011), p. 15.

30 Kersten, Islam in Indonesia, p. 246.

31 Ramon Panikkar, The Intra-Religious Dialogue. (Mahwah: Paulist Press, 1999), p.5-11.

32 Melissa Crouch. "Indonesia, Militant Islam and Ahmadiyah: Origins and Implications: ARC Federation 
Rigid Salafist type Muslims understandably detested these young Muslim intellectuals, mainly from JIL. ${ }^{33}$ Simultaneously, the Islamic liberal movement led by JIL also failed to attract public support, for they were regarded as another form of extremism. ${ }^{34}$ While JIL and other liberal Muslims struggled with the growing Salafist trend, the two major components of the umat, NU and Muhammadiyah, were rather slow responding "to the rise of reactionary Muslim activism and the subsequent conservative turn", as Kersten points out. ${ }^{35}$ Although Ulil Abshar Abdalla was deeply connected with Gus Dur as a member of NU, young liberal Muslim intellectuals received little earnest support and acknowledgement from NU.

Despite the fact that there were quite a few young liberal intellectuals who were members of NU and Muhammadiyah, these two mass organisations with various components were never able to be as liberal as JIL. With regard to their stance on Ahmadiyah, both $\mathrm{NU}$ and Muhammadiyah have refused to accept this controversial group as Islam since pre-Independence times. ${ }^{36}$ More recently, Ma'ruf Amin, a chairperson of Majelis Ulama Indonesia, and one of the executives of NU, reiterated that Ahmadiyah cannot be regarded as a form of Islam in 2018. ${ }^{37}$ Conforming to this inclination, NU and Muhammadiyah have adopted the somewhat inclusive practice of accepting it as a non-Islamic religion.

Generally, the umat more or less showed its quadripartite tendency in the post-New Order times. First, rigid hardliner Muslims, whose ultimate purpose is to implement syariat, have had a secure base for propagation activities since the time of Reformasi. This group can be categorised as exclusivist. However, they have no intention to eliminate nonMuslims from society by force, provided that non-believers never bother their religious activities. The second group employs barbaric acts of terrorism in order to realise their religious purposes. Although this group is proportionally small, the impact it has on society is rather immense. Liberal Muslims, especially young intellectuals, who can be considered pluralists by Panniker's account, constitute the third group. Due to their outspokenness and promotion of secularism, this group encounters ostracism from the masses, who dislike being perceived as "un-Islamic". NU and Muhammadiyah form the major component of the umat. These influential mass Islamic organisations have distanced themselves from the other three groups. The current socio-political order in the Republic is primarily the result of their activities, and both organisations aim to avoid Salafist extremism and liberal extremism. NU and Muhammadiyah, needless to say, cannot be understood as the two sides of the same coin, as they still have their own social, political, and religious agendas, respectively. However, as Latif points out, they share the same values of "democracy, social justice and welfare" and they have "inspired social, economic and educational programs

Fellowship Islam, Syariah and Governance”. Background Paper Series 4. Melbourne: Centre for Islamic Law and Society \& Melbourne Law School, 2009. p. 12: Kersten. Islam in Indonesia, p. 256.

33 Muhammad Ali. "The Rise of Liberal Islam Network (JIL) in Contemporary Indonesia." The American Journal of Islamic Social Sciences 22, no.1, (2005), p.20.

34 “Indonesia Tanpa FPI vs Tanpa Indonesia JIL", 30 May, 2012, Dakwatuna available at: https://www. dakwatuna.com/2012/05/30/20805/indonesia-tanpa-fpi-vs-indonesia-tanpa-jil/\#axzz6VGpY4uDT

35 Kersten, Islam in Indonesia, p. 249.

36 Jeremy Menchik, Islam and Democracy in Indonesia. (Cambridge: Cambridge University Press, 2016), p.75.

37 BBC News Indonesia, 19 February, 2018, available at: https://www.bbc.com/indonesia/indonesia-42642858 Ma'ruf Amin was paired with Joko Widodo as a vice-presidential candidate and was elected as vice president of the Republic in 2019. 
throughout the country".38

\section{Religion as Organism}

The categorisation of the umat into four groups might be too simplistic since there are a numerous Islamic organisations and individual activities in Indonesia. Yet, each group explained above represents a general trend within the umat. One might wonder which trend epitomises "true Islam"? In other words, why do we find different attitudes and ideas among the followers of the same religion? V.S. Naipaul casts doubt on the uniformity of religion: "Religious or cultural purity is a fundamentalist fantasy". ${ }^{39}$ Various fields of study have dealt with religions in academic history. Theology, for example, focuses on the textual analysis of a religion's teachings and attempts to grasp the fundamental truth or essence of that religion. Theologians approach religions from a literal point of view; however, it is equally important to understand religions from a socio-cultural point of view, which attends to the relationships between the teachings and the followers within their sociocultural environment. Abdul Karim Soroush has argued,

... one can say that the text does not stand alone, it does not carry its own meaning on its shoulders, it needs to be situated in a context, it is theory-laden, its interpretation is in flux, and presuppositions are as actively at work here as elsewhere in the field of understanding. Religious texts are not exception. Their interpretation is subject to expansion and contraction according to the assumptions preceding them and/or the questions enquiring them. ${ }^{40}$

Soroush emphasises the necessity of employing not only theoretical reasoning but also scientific analysis to understand that "religion is divine, but its interpretation is thoroughly human and this-worldly". ${ }^{41}$

Religions in this sense can be seen as a response to social phenomenon. The truth might be hidden in the text; however, humans are still required to search for it by themselves, and the results of individual searches or interpretations could differ from one another. Therefore, the fact that the umat in Indonesia shows several contrasting features is a natural development in the religious community. NU, for example, adopted Islam Nusantara as the theme of its conference (Muktamar) held in 2015. ${ }^{42}$ This move was severely criticised and denounced by rigid hardliner Muslims. A. Rohim believes that it was a deviation from the truth of Islam. ${ }^{43}$ Knowing these conflicting views in the umat in Indonesia, we again have to wonder whether there is a more comprehensive view for understanding Islam.

Salafist type rigid Muslims prioritise literal understandings of the teachings based on the holy scriptures and have ardently attempted to revive the norms and traditions from the time of the Prophet Muhammad. They even grow their beards following the Hadith.

38 Hilman Latief, “The Future Challenges for Indonesian Islam.” The Jakarta Post, 7 August 2015, available at: https://www.thejakartapost.com/news/2015/08/07/the-future-challenges-indonesian-islam.html

39 Vidiadhar Surajprasad Naipaul, Beyond Belief. (New York: Vintage Books, 1998), p.59

40 Abdul Karim Soroush. “The Evolution and Devolution of Religious Knowledge.” In Kurzman, C.(ed.).

Liberal Islam. (New York: Oxford University Press, 1998), p. 245.

41 Soroush, “The Evolution and Devolution,” p. 246.

42 For more details see Hisanori Kato, "Religion and Locality: The Case of the Islam Nusantara Movement in Indonesia." Fieldwork in Religion 13, No. 2, (2018).

43 Interview with the author, Solo, 18 March, 2018. 
Furthermore, it is common in Indonesia that once friendship is established, a non-kindred "mate" is considered a related family member. Pluralists usually have no reservations about nurturing this relationship with non-Muslim friends. On the contrary, religiously rigid Salafist Muslims refuse to admit non-Muslims as family members. The author, as a nonMuslim, has had such a personal experience with a hardliner Muslim friend, who politely refused to recognise the author as his "brother".

On another occasion, some hardliner Muslim friends invited the author to convert to Islam-which rarely takes place with pluralist liberal Muslims-under the pretext that the author would otherwise never be accepted in Heaven in the afterlife. Their invitation was by no means forcible, as Islam forbids compulsive conversion. ${ }^{44}$ Their invitation was based on their compassion for a non-Muslim, and their deed surely originated from their exclusivist idea that their own faith, Islam, is the highest and only true religion. We can hardly criticise their literalist interpretation of Islam and their attitude as discriminative or evil; rather, they merely follow what they believe has been bestowed by Allah and recorded in al-Quran. These rigid Salafist type exclusivists seem to struggle in creating a purely "Islamic society" defined and arranged by al-Quran and the Hadith, which has not yet materialised in modern society. In this kind of "Islamic society", there is little room for a "science of religion" as proposed by Soroush. ${ }^{45}$

Compared with exclusivists rigid Muslims, pluralist liberal Muslims in Indonesia attach great importance to socio-cultural conditions in deciding their religious attitude. They believe that Islam must face modernity and be reconciled with it. ${ }^{46}$ This view resonates with the ideas of An-Na'im, who states that “...the Qur'an and Sunna have been the source of Shari'a as the Islamic response to the concreate realities of the past and must be the source of modern Sharia as the Islamic response to the concrete realities of today" ${ }^{47}$ Their active practice of ijtihad was an ideal framework for a multi-religious society without a syariatbased legal system. ${ }^{48}$

Indonesian pluralist ideas are tantamount to Islamic reformist reasoning (including that of Soroush) which values various fields of studies, including philosophy, politics, sociology, and history, and encourages a "re-shuffling the traditional suppositions". ${ }^{49}$ According to the pluralists, gender equality, inter-religious marriage, and the issue of human rights matter for creating and maintaining an amicable relationship among humans whose cultural as well as religious backgrounds vary. The author knows through informal discussions with pluralist Muslims that some are brave enough to recognise Ahmadiyah's contention about the prophecy and that some accept Ahmadiyah members as fellow Muslims. Whereas exclusivist Muslims are in the process of creating an Islamic society, pluralist Muslims reside in a Muslim society, where human reasoning operates and where societal conditions change or-as is more accurate to say-progress. ${ }^{50}$

\footnotetext{
44 There shall be no compulsion in religion, al-Quran: al-Baqarah 256.

45 Soroush, "The Evolution and Devolution," p. 245-246.

46 Ali, "The Rise of Liberal Islam," p. 10.

47 An-Na’im, A.A. (1996). Toward an Islamic Reformation. New York, pp.143-144.

48 Ali, “The Rise of Liberal Islam," p.10.

49 Soroush, "The Evolution and Devolution," p. 250.

50 See Kato, "Religion and Locality".
} 
Thus, there seems to arise doubt as to which group possesses the truth about Islam. From a literal perspective, exclusivist groups maintain tradition and authenticity in behaviour. On the other hand, pluralists also draw upon traditions of Islam, including the al-Quran and Hadith, with social conditions and changes in mind. Therefore, it is fallacious to conclude that they are un-Islamic. The Muslims who are more open-minded towards reformations of Islam are also genuine Muslims. A useful way of referring to Islam in a comprehensive manner is to use "ISLAM" (in all caps) to mean both Islamic society, upheld by exclusivist Muslims, and Muslim society, where liberal Muslims and probably the majority of Muslims in Indonesia reside. The former society is in the process of materialisation and is religiously rigid and uncompromising, while the latter is rather flexible and unconventional. The vast number of Indonesian Muslims are not affiliated with mass organisations, and their worldly interests are likely greater than their willingness learn Arabic to understand al-Quran in the original. They also do not hesitate to express their wishes to their ancestors and the spirits living in nature, which is conventionally forbidden in Islam. The degree of behavioural authenticity for these Muslims is surely lower, yet we cannot exclude them from ISLAM.

We next need to consider where terrorist Muslims and the mainstream of the umat, such as NU and Muhammadiyah, are to be placed in this account. Terrorist acts are derived from an ideology of utter acceptance of indiscriminate killings of fellow humans regardless of their religion. This notion is by no means in accordance with the idea of jihad and the teachings of Islam. Therefore, terrorists should be distinguished from so-called "exclusivist rigid Muslims". Nevertheless, it is erroneous to conclude that these violent-driven Muslims are not Muslims. Because they exercise their ijtihad, interpreting jihad "unconventionally" in their own way, they can be regarded as the residents of Muslim society. It is obvious that harmless liberal Muslims, less pious Muslims, and violent harmful Muslims all coexist in so-called Muslim society.

The position of large-scale organisations such as NU and Muhammadiyah seems to oscillate in the world of ISLAM, as both avoid placing themselves among the extreme positions of rigid exclusivists and liberal pluralists. Even though Muhammadiyah focuses on their own academic and social activities and approve of the status-quo, we still know that some elements of this modernist organisation are willing to "purify" Islam. They also intend to adjust themselves to modernity, as is signified by Muhammadiyah's launch of Islam Berkemajuan ${ }^{51} \mathrm{NU}$ also shows a similar stance in their tolerance of Indonesian cultural traditions within Islam, while the purity of Islam within Islam Nusantara is emphasised..$^{52}$ In this sense, these mass organisations travel back and forth between Islamic society and Muslim society, and on most occasions, they stay somewhere in-between in the world of ISLAM.

The dispositions of these Muslim groups suggest that Islam qua religion should be understood as an organic entity, which is "reflective of social circumstances and changes". ${ }^{53}$

51 Kato, "Religion and Locality", p. 161.

52 Kato, "Religion and Locality," p. 157.

53 Hisanori Kato, "Social Demand and the "Clash of Ijtihad": A Constructionist Approach to Current Islamic Movements in Indonesia." In Kato, H. (ed.), The Clash of Ijtihad, Fundamentalist versus Liberal Muslims. (Delhi: ISPCK, 2011), p. xv. Also see, Hisanori. Kato, Agama dan Peradaban. (Jakarta: PT. Dian Rakyat, 2002), p. 306. and Hisanori Kato, "Religion and Locality: The Case of the Islam Nusantara Movement in Indonesia." Fieldwork in Religion 13, no.2, (2018), p.151-168. 
Islamic society is probably less responsive towards social changes, yet it is still a part of ISLAM, where various unconventional interpretations and worldly approaches to Islam are instigated. Thus, ISLAM as a whole cannot persistently keep an immutable form. In other words, debates and disagreements taking place among groups in the umat are congenital aspects of the organic social entity ISLAM.

Some scholars tend to only designate pluralist Muslims and moderate NU and Muhammadiyah as "good and genuine Muslims", and they believe that non-Muslims should strengthen their relationships with these comfortable allies. This favouritism is misleading, as the concept of ISLAM as a whole is disregarded. Many would agree that acts of terrorism should never be tolerated; however, this is only possible if all types of Muslims work together in political and cultural matters. Such efforts should be continuously made by non-Muslims, especially in matters related to the Islamophobia explicitly exhibited in the West. Yet as these external endeavours would be insufficient in bringing an end to all such problems, inter-Muslim dialogue, debates, and activities within ISLAM and the umat must also occur.

There seem to be numerous debatable and controversial issues within the umat, such as the preferred political and legal system and national policies on multi-culturalism. However, we find a looming issue crucial for the creation of stability and tolerance in society: de-radicalisation of former terrorists. In what follows, the paper will attempt to present the current conditions and the crux of the contention related to this issue.

\section{The De-radicalisation of Former Terrorists}

Prior to discussing de-radicalisation, we need to clarify the semantic meaning of certain terms related to terrorists and other hardliner Islamic movements. The English word "radical" originates from the Latin word "radix", which means "root" or "first". ${ }^{54}$ Following the original meaning of "radical", de-radicalisation means the elimination of authenticity or originality.

Only Islamophobics, who believe that the original teaching of Islam is violent, can use the word "de-radicalisation" to refer to making terrorist Muslims peaceful. The author, therefore, is reluctant to employ the word "radical" to describe terrorists. In reality, the word is commonly used to describe both terrorists and rigid Muslims, and it carries an extremely negative connotation in the non-Islamic world. By the same token, the term "fundamentalist", which originally meant "beginning" or "foundation", is not used in this paper. The author has opted to use the term "de-radicalisation" in what follows, as the word seems to have become a common noun for describing the process of rehabilitating former Muslim terrorists.

As previously mentioned, Indonesia has encountered several acts of terrorism conducted by Muslims in its modern history. Some of the perpetrators of these acts were executed, and some were imprisoned according to their misdeeds. From 2010 onwards, former terrorists began to be released, having completed their terms of imprisonment. One of the central concerns in Indonesia has been whether the former terrorists have had a change of heart. If they have not abandoned their violent ideology, their de-radicalisation is an urgent

54 Kato, The Clash of Ijtihad, p. xvi. 
requirement for the prevention of further terrorist attacks.

Zuhri explains that three different achievements are sought through a de-radicalisation programme: ideological de-radicalisation, behavioural de-radicalisation, and organisational de-radicalisation. ${ }^{55}$ As a governmental institution, Badan Nasional Penanggulangan Terorisme (National Counter Terrorism Agency or BNPT), which was authorised to handle anti-terrorism activities in 2010 by a Presidential decree known as Desk Koordinasi Pemberantasan Terorisme (Eradication Terrorism Coordinating Desk or DKPT), has played a key role in the de-radicalisation of former Muslim terrorists in Indonesia. BNPT works with 36 ministries and governmental agencies to combat terrorism. ${ }^{56}$ They organise various programmes; however, they seem to focus on behavioural and organisational deradicalisation rather than ideological.

The core principles behind behavioural de-radicalisation programmes are twofold: prevent and inform. There are various programmes designed for the younger generation, who are the target of terrorist recruitment. For example, BNPT created a programme called "the Ambassadors of Peace", which involves the youth disseminating messages about the importance of peace and cooperation among religions through social networks. Eight hundred-sixteen youths participated in this programme across thirteen cities in Indonesia nation-wide by March, 2019. ${ }^{57}$ BNPT has also provided the public with information about the mindset and experiences of former terrorists through seminars and lectures usually held at public venues, such as hotels. However, BNPT employs no "formal theological dialogue", which can be linked with ideological de-radicalisation. ${ }^{58}$ Rather than direct persuasion, Indonesian authorities more frequently take an indirect method to soften the attitudes of former terrorists; they speak to the terrorists in their local languages and treat them in a humane manner. ${ }^{59}$ Even when BNPT attempts to instil a non-violent ideology in former terrorists, they still take a cultural approach and present the idea of peace via an Indonesian puppet show, or wayang kulit. ${ }^{60}$

BNPT also works with mass organisations, including NU. The chairperson of NU, K. H. Said Aqil Siraj, also believes that his organisation should be a part of the de-radicalisation programme, althoughheadmits that theeradication ofterrorismitselfmightbestbeconducted by BNPT and other institutions. ${ }^{61}$ The collaborative de-radicalisation programmes include seminars for the leaders of mosques, Islamic boarding schools(pesantren), universities, and other educational institutions. ${ }^{62} \mathrm{NU}$ alone offers informal religious education and training to the public. For example, NU organises a six-month-long course at its headquarters in Jakarta, and pesantren leaders, schoolteachers, private employees, and youth as young as high school students attend this course. ${ }^{63}$

Although two major Islamic organisations seem to have little objection to the idea of

55 Saefudin Zuhri, Deradikalisasi Terorisme. (Jakarta, Daulat Press, 2017), p. 106.

56 Harianto, BNPT, interview with the author, Jakarta, 19th March, 2019.

57 Harianto, BNPT, interview with the author, Jakarta, 19th March, 2019.

58 Angel Rabasa (et al.), Deradicalizing Islamist Extremists. (Santa Monica: Rand Corporation, 2010), p. 107.

59 Rabasa (et al.), Deradicalizing. 107-108

60 Zuhri, Deradikalisasi Terorisme. p.114.

61 Zuhri, Deradikalisasi Terorisme. p.115.

62 Zuhri, Deradikalisasi Terorisme. p. 115.

63 This was held in the headquarters of NU in Jakarta. The author observed the class on $10^{\text {th }}$ March, 2018. 
de-radicalising former terrorists, NU and Muhammadiyah have different opinions on the cause of terrorism. While NU believes that radicalism is derived from Wahabism, Muhammadiyah considers it to be the result of a grudge held by some Muslims towards governmental policies, such as unjust aspects of the legal system, economic inequality, and the feeling of being marginalised. ${ }^{64}$ BNPT worked with NU between 2011 and 2013, but not with Muhammadiyah. ${ }^{65}$ Zuhri suggests that these two organisations are able to contribute to the prevention of the further growth of terrorism in Indonesia by assisting the offspring of terrorists and inducing a peaceful ideology through promotional activities ${ }^{66}{ }^{\text {In }}$ this regard, these major components of the umat have great potential for assisting de-radicalisation programmes through various means.

Apart from BNPT, there are non-governmental organisations that are actively involved in de-radicalisation programmes. Among others, these include the Indonesian Muslim Crisis Centre (IMCC), Yayasan Prasasti Perdamaian (YPP), Peace Generation, and Aliansi Indonesia Damai (AIDA). The founders of these NGOs are mainly academics and civilian activists, and their focus is to provide practical assistance to former terrorists, including job training, job recruitment, and financial loans. The degree of their success should not be hastily assessed; however, the obstacle they currently face is an insufficiency of funds to run their programmes. Therefore, some of them have attempted to stabilise their finances by creating their own enterprises. IMCC and YPP, for instance, opened restaurants in Jakarta and Solo, respectively. ${ }^{67}$

The most crucial and probably most challenging part of the de-radicalisation process is how former terrorists can alter their violent mindset, which is intricately connected with the ideological aspect of Islam. However, the three major players in de-radicalisation programmes-the government institution BNPT, the major components of the umat (NU and Muhammadiyah), and civilian-run NGOs-have encountered obstacles in establishing a forthright theological medium for bringing about such a metamorphosis in the minds of former terrorists.

From a terrorist perspective, BNPT could be seen as the greatest agent for the suppression and marginalisation of fellow Muslims hitherto. As former terrorists might still distrust the government, they are reluctant to engage in in-depth discussions about their Islamic ideology, not only with BNPT but with any government-affiliated institutions. NU and Muhammadiyah in some respects have been collaborators with the government, at least in the post-Suharto era with their endorsement of the Pancasila ideology, which conflicts with that of the terrorist. Thus, these two large organisations are still held at a distance by former terrorists, who are sceptical towards them. Civilian-run NGOs, on the other hand, focus on practical support for former terrorists after their release, and they organise activities to prevent the spread of violent ideology rather than attempt to change their minds.

With regard to religious ideology, hardliner rigid Muslims take the closest stance to former terrorists. For example, both never abandon physical struggle in the face of an

64 Zuhri, Deradikalisasi Terorisme. p. 162.

65 Zuhri, Deradikalisasi Terorisme. p. 162.

66 Zuhri, Deradikalisasi Terorisme. p. 158-159.

67 Sambal Bang Dame is a small canteen with a cosy atmosphere run by IMCC in Jakarta, and a restaurant specialised beef steak, Dapoer Bistik, is run by YPP in Solo, Central Java. 
enemy. What distinguishes these two groups, however, is the prospect of jihad. While rigid hardliner Muslims strictly follow the teachings on jihad stated in holy scriptures- and thus their struggle is far from indiscriminate killings- terrorists lack such prudence, which has resulted in the random slaughter of both fellow Muslims and non-Muslims. Yet the groups still seem to have a mutual understanding, as rigid hardliner Muslims will sometimes say "terrorist acts are wrong, but the intention is understandable". ${ }^{8}$

Accordingly, interaction between rigid hardliners and former terrorists can be effective in ideological de-radicalisation. A potentially even more effective means of altering the mind of terrorists is interaction among former terrorists themselves. Presumably, the degree of remorse will differ from one former terrorist to another. Those already substantially cognizant of their misdeeds are more persuasive than any other Muslim in the umat in deradicalising former terrorists who still persistently attach themselves to a violent ideology.

In fact, there are several former terrorist figures who are actively involved in the process of de-radicalising fellow former terrorists. Some of them have established their own organisations, although small in scale, with the purpose of correcting misguided Muslim ideologies and helping the peaceful aspects of Islam to prevail. A former terrorist Joko Tri Hermanto- known as Jack Harun, who was involved in the Bali Bombing of 2002established an organisation with the purpose of "supporting ex-terrorists to re-integrate in society and making them have a human life again". 69

His organisation, called Gema Salam, accepts former terrorists as members and provides them with opportunities to feel that they are a part of society and useful for fellow humans. Jack Harun and his "mates" regularly visit schools to share their experiences with young pupils. ${ }^{70} \mathrm{He}$ also organises meetings with the police and released former terrorists in order to eradicate mistrust among them. These activities are independently planned and executed without specific support from the government. ${ }^{71} \mathrm{He}$ opened a small canteen for traditional chicken soup in the suburb of Solo in order to secure his finances and continue his activities.

When he invites former terrorists to join him, he shares his experiences and conveys two messages: That it is wrong to employ any act of violence to realise a religious purpose, and that it is good to make family happy. ${ }^{72}$ As a former advocate of terrorism, Jack Harun is able to analyse his own path to becoming a terrorist, which serves a useful function when he attempts to de-radicalise strong-willed terrorists. On occasion, however, Jack Harun fails to persuade former mates to abandon their terrorist ideologies. For example, one of his former terrorist friends, who was on the run with him before their arrest, rejected Jack Harun's suggestions and opinions. This took place when Jack Harun himself visited his friend in prison in 2008, and they have never met since. Jack Harun said that "I did everything I could do for him, but there was nothing I could do after he rejected me". ${ }^{73}$

68 This view has been frequently expressed to the author through numerous informal discussions with rigid hardliner Muslims.

69 Interview with the author, Solo, 11 March 2019.

70 Since its establishment in December 2018, they have visited 20 schools by January 2020. Jack interview 1 January 2020.

71 Interview with the author, Solo, 1st January, 2020.

72 Interview with the author, Solo, 1st January, 2020.

73 Interview with the author, Solo, 1st January, 2020. 
Harris Amir Falah is another "remorseful Muslim", who was arrested in 2010 and charged with funding a military camp in Ace. Falah shares his experiences not only with former terrorists but also with potential terrorists who are exposed to violent ideologies. Falah even visited a prison to have a dialogue with ISIS supporter Abu Mubarok, and he has held preaching sessions for young lecturers at the pesantren run by Mubarok. ${ }^{74}$ Despite suspicion and tacit dissent from the participants, Falah feels that his message about the denial of extremism has started to instil itself in the hearts of young Muslims who could turn to takfiri. ${ }^{75}$

There are other former terrorists who also actively campaign against violent attitudes and ideologies in Islam. They seem to have changed their mindset and have willed to make themselves useful for society. These include Yudi Zulfahri, who established Jaring Perdamaian; Kurnia Widodo, who established Genggam Perdamaian; and Ali Fauzi, who established Yayasan Lingkar Perdamaian. Although the establishment of these organisations is meant to support former terrorists who wish to change their religious ideology and be reintegrated into society, their activities are still premature: the founders themselves have not yet been reintegrated into society. These former terrorists find it difficult to obtain a proper occupation. Kurniawan Widodo admits that his organisation is not fully operational yet. $^{76}$

Terrorism perpetrated in the name of Islam is one of the most serious predicaments that the umat is encountering in contemporary Indonesia. There are various so-called "deradicalisation programmes", which are initiated and executed by government institutions, civilian-led NGOs, large scale Islamic organisations, rigid hardliner exclusivists, and individual former terrorist themselves. However, the assessment of these activities should not be made prematurely: long-term observations on the degree of their re-integration into the society is necessary. Nonetheless, our observations suggest that assistance to the former terrorist initiators of these programmes from the rest of the umat as well as the government would expedite the de-radicalisation process since these initiators have a psychological affinity with their former "mates".

\section{Conclusion}

Islam has been an important social element in Indonesia. Its socio-political stance has exerted its influence across the country. At the same time, the umat in Indonesia has never been united as a single force. The umat has been divided due to cultural, social, and political issues, and even interpretations of religious teachings. The implementation of syariat is one of the causes behind this discord in the umat. Differing political strategies between important members of the umat have also caused disagreement, which was, for instance, observed in the time of the establishment of ICMI

During the post-Suharto era, Indonesia has witnessed several cases of terrorism. Following the release of some of the perpetrators of terrorism, the issue of de-radicalising former terrorists became crucial. Since access to terrorists who steadfastly cling to violent ideologies is limited, de-radicalisation is one of the most serious predicaments that the

74 Haris Amir Falah, Hijrah dari Radikal kepada Moderat. (Jakarta: Milenia, 2019), p.117-127

75 Interview with the author. Lebak Bulus, 17th February, 2019.

76 Interview with the author, Bandung, 12th March, 2020. 
umat has to deal with in contemporary Indonesia.

Each group of the umat, however, seems to have its own role to play in de-radicalisation. Pluralists have no direct access to former terrorists, yet they are still able to collaborate with civilian-run NGOs to develop terrorism-preventive programmes for the public. Major Islamic organisations, such as NU and Muhammadiyah, are also able to spread a moderate Islamic ideology to their members and the schools they run through educational programmes. These large-scale organisations can be competent partners for the government when religious assurance is required in BNPT programmes.

The most prospective educators of de-radicalisation programmes are rigid hardliner exclusivist Muslims and former terrorists who have shown regret for their actions. Nonetheless, these two Muslim groups can hardly accomplish their goals without assistance and collaboration provided by other groups in the umat. Such "assistance and collaboration" are still possible even without complete agreement and total reconciliation within the umat; however, what is required is the commitment of each group based on their own capacity. For example, some affluent groups might offer funding for the programmes if they are not a main organiser. Some are also able to offer opportunities to discuss core ideas of Islam from various perspectives, such as exclusivist, pluralist, and terrorist points of view in order to clarify the inadequacy of the idea of indiscriminate killings. Insofar as discussions continue, there will be no final physical confrontation.

In conclusion, Islam-and religion in general-naturally develops as an organism with different religious attitudes and interpretations. Thus, the divisions that we see in the umat in Indonesia are not peculiar. As long as non-Muslim favouritism to only "good Muslims" persists, there will be no genuine mutual understanding between the Islamic and non-Islamic worlds. Simultaneously, the reality of the umat in Indonesia seems to suggest that if Muslims in Indonesia wish to overcome their predicaments, including the de-radicalisation of former terrorists, Muslims themselves must understand the divisions in the umat and endeavour to maintain continuous internal discussions. 


\section{References}

Abdalla, Ulil Abshar. "Menyegarkan Kembali Pemahaman Islam”. Kompas, 18 November, 2002.

Ali, Muhammad. "The Rise of Liberal Islam Network (JIL) in Contemporary Indonesia." The American Journal of Islamic Social Sciences 22, no.1, (2005).

An-Na'im, Abdullah Ahmed. Toward an Islamic Reformation. New York: Syracuse University Press, 1996.

Aspinall, Edward. Opposing Suharto. Stanford: Stanford University Press, 2005.

Assyaukanie, Luthfi. "Debates on Islam and Secularism in Indonesia." In Kato, Hisanori (ed.) The Clash of Ijtihad, Fundamentalist versus Liberal Muslims. Delhi: ISPCK, 2011.

Bresnan, John. Managing Indonesia. New York: Columbia University Press, 1993.

Cribb, Robert and Brown, Collin. Modern Indonesia A History since 1945. London: Longman, 1995.

Crouch, Melissa. Indonesia, Militant Islam and Ahmadiyah: Origins and Implications:

$A R C$ Federation Fellowship Islam, Syariah and Governance Background Paper Series 4. Melbourne: Centre for Islamic Law and Society \& Melbourne Law School, 2009.

Falah, Haris Amir. Hijrah dari Radikal kepada Moderat. Jakarta: Milenia, 2019.

Goto, K. Tonanajia karmita Kindain Nippon (Modern Japan from Southeast Asian Prespectives). Tokyo: Iwanamishoten, 2012.

Legge, John David. Indonesia. Englewood Cliffs: Prentice-Hall, 1964.

Kato, Hisanori. "Religion and its Functions in Society: Islam and the Creation of a Democratic Civilised in Indonesia with Special Attention to Nahdlatul Ulama, Muhammaidyah and Ikatan Cendekiawaan Muslim se-Indonesia," Ph. D thesis, The University of Sydney, 1999.

-----. "Religion and Locality: The Case of the Islam Nusantara Movement in Indonesia." Fieldwork in Religion 13, No. 2, (2018).

---------. (ed). The Clash of Ijtihad, Fundamentalist versus Liberal Muslims. Delhi: ISPCK, 2011. . "Social Demand and the "Clash of Ijtihad": A Constructionist

Approach to Current Islamic Movements in Indonesia." In Kato, Hisanori.(ed). The Clash of Ijtihad, Fundamentalist versus Liberal Muslims. Delhi: ISPCK, 2011.

. Agama dan Peradaban. Jakarta: PT Dian Rakyat, 2002.

Kersten, Carool. Islam in Indonesia The Contest for Society, Ideas and Values. London: Hurst \& Company, 2005.

Kurzman, Charles. (ed.) Liberal Islam. New York: Oxford University Press, 1998.

Menchik, Jeremy. Islam and Democracy in Indonesia. Cambridge: Cambridge University Press, 
2016.

Mizumoto, T. Indonesia. Tokyo: Chuokoron-Shinsha, 2006.

Naipaul, Vidiadhar Surajprasad. Beyond Belief. New York: Vintage Books, 1998.

Natsir, Muhammad. “The Indonesian Revolution," in Kurzman, Charles (ed.). Liberal Islam. New York: Oxford University Press, 1998.

Panikkar, Ramon. The Intra-Religious Dialogue. Mahwah: Paulist Press, 1999.

Ricklefs, Merle Calvin. A History of Modern Indonesia Since c. 1300. London: Macmillan, 1993.

Islamisation and Its Opponents in Java c.1300 to the Present,

Honolulu, 2012.

Soroush, Abdul Karim. "The Evolution and Devolution of Religious Knowledge." In Kurzman, C.(ed.). Liberal Islam. New York: Oxford University Press, 1998.

Syamsuddin, M. Sirajuddin. "Religion and Politics in Islam: The Case of Muhammadiyah in Indonesia's New Order." Ph. D thesis, UCLA, 1991.

Rabasa, Angel (et al.) Deradicalizing Islamist Extremists. Santa Monica: Rand Corporation, 2010.

Wahib, A. B. Liberal Islam in Indonesia. Saarbrucken: Lambert Academic Publishing, 2012.

Zuhri, Saefudin. Deradikalisasi Terorisme. Jakarta, Daulat Press, 2017.

\section{Website}

Dakwatuna:

"Indonesia Tanpa FPI vs Tanpa Indonesia JIL", 30 May, 2012: https://www.dakwatuna. com/2012/05/30/20805/indonesia-tanpa-fpi-vs-indonesia-tanpa-jil/\#axzz6VGpY4uDT

(accessed on 15 August 2020)

Pew Research Centre, Religion and Public Life: https://www.pewforum.org/2010/11/04/muslim-population-of-indonesia/

(accessed on 16 August, 2020)

The Jakarta Post

H. Latif, “The Future Challenges for Indonesian Islam”, in The Jakarta Post 7 August, 2015, available at: https://www.thejakartapost.com/news/2015/08/07/the-future-challenges-indonesian-islam.html (accessed on 15 August 2020)

World B-ank:

https://www.worldbank.org/en/country/indonesia/overview (accessed on 15 August 2020) 


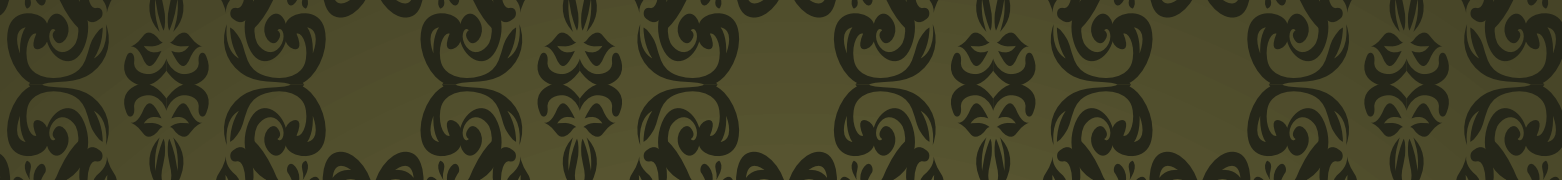

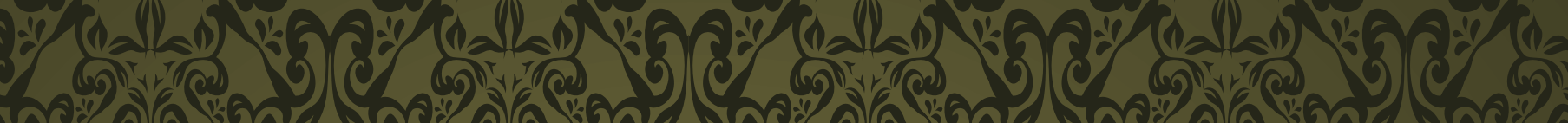

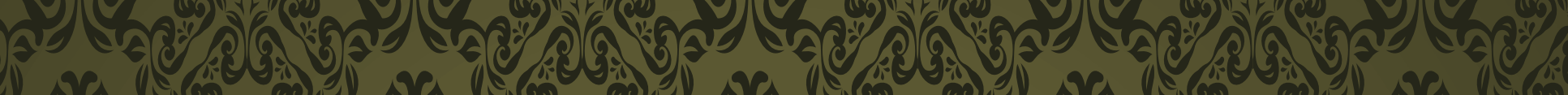

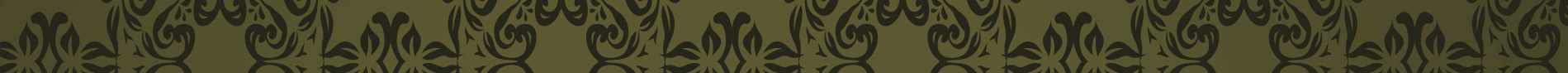

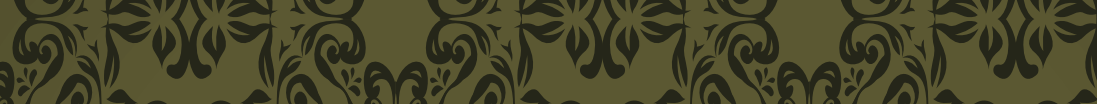

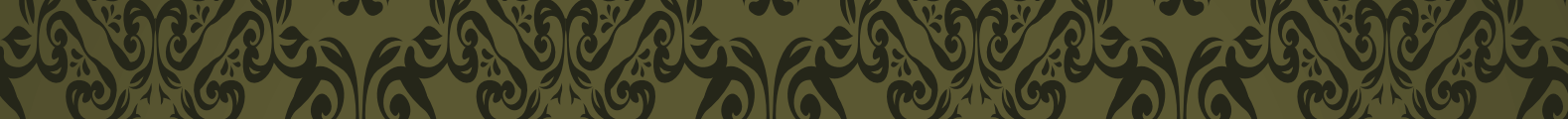

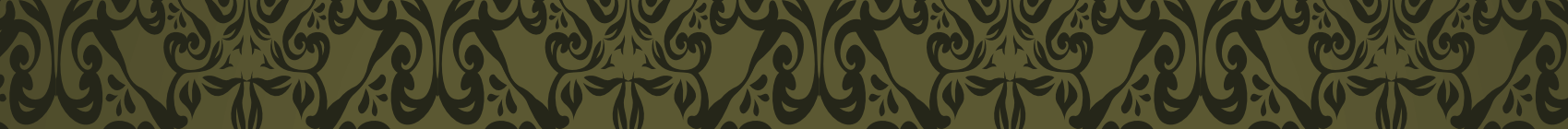
(1)

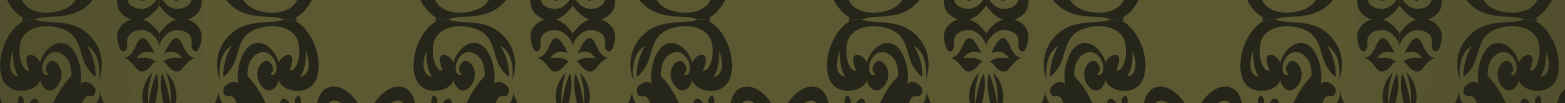

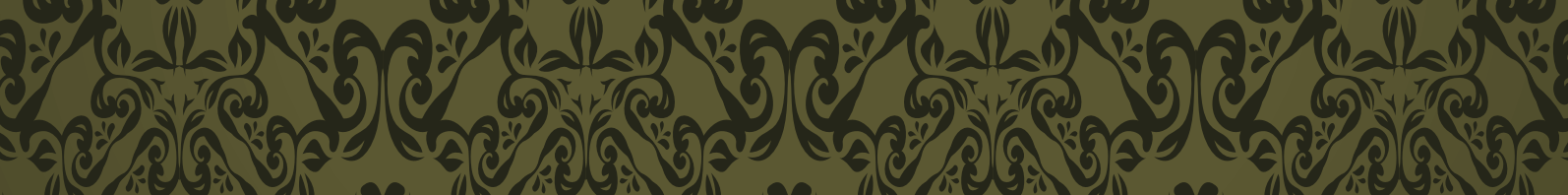

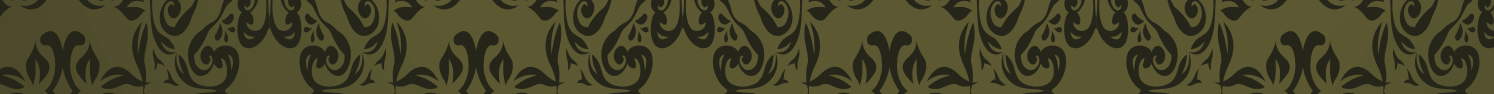
(1) $)(1)$ 5.

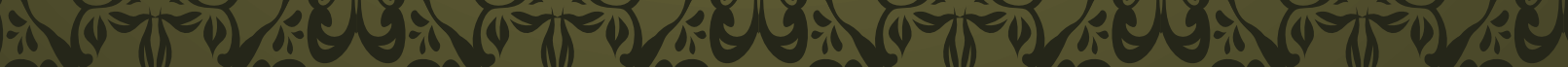

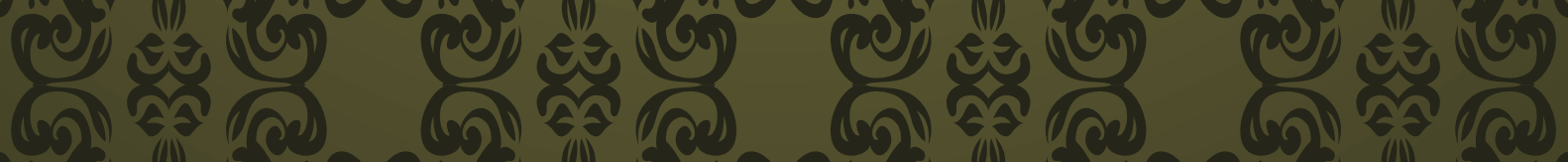

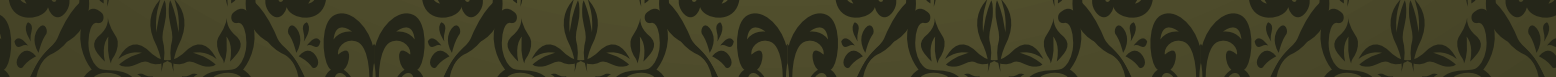
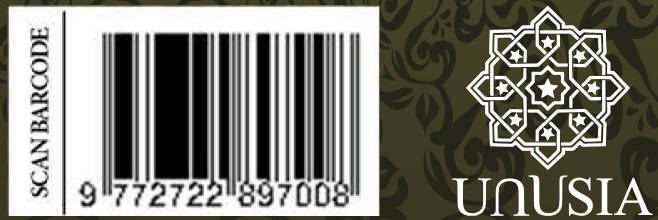

Volume II | E-ISSN 2722-8975

Fakultas Islam Nusantara

Universitas Nahdlatul Ulama Indonesia Jakarta 